\title{
CD47 is Up-Regulated on Leukaemia Cells to Avoid Apoptosis in Vitro
}

\author{
Ikenna Kingsley Uchendu ${ }^{1}$, Oliver Chukwuma Orji ${ }^{1}$, Chidozie Elochukwu Agu² ${ }^{2}$, Blessing Eluke Chekwube ${ }^{3}$, Tochi Faith Nwosu ${ }^{4}$ \\ ${ }^{1}$ Division of Clinical Chemistry, Department of Medical Laboratory Science, University of Nigeria Enugu Campus, Nigeria. \\ ${ }^{2}$ Prime Health Response Initiative (PHRI)-Global Fund HIV/AIDS Project, Ilorin, Kwara State, Nigeria. \\ ${ }^{3}$ Division of Haematology/Blood Group Serology, Department of Medical Laboratory Science, University of Nigeria Enugu Campus, Nigeria. \\ ${ }^{4}$ Barnes Hospital and Cardiac Diagnostic Laboratories Ltd. 34b, Yesufu Abiodun Oniru Road, Dideolu Estates, Victoria island extension, Lagos, Nigeria.
}

\begin{tabular}{|c|c|}
\hline ARTICLE INFO & ABSTRACT \\
\hline $\begin{array}{l}\text { Article history: } \\
\text { Received on: } 12 / 05 / 2017 \\
\text { Accepted on: } 27 / 10 / 2017 \\
\text { Available online: } 30 / 03 / 2018\end{array}$ & $\begin{array}{l}\text { Treatment failure in T-cell acute lymphoblastic leukaemia (T-ALL) occurs when leukemic blasts acquire resistance to } \\
\text { chemotherapeutic agents. Current research efforts are focused on the search for targets for the development of more } \\
\text { effective and less toxic anti-leukemic drugs. CD } 47 \text { has been suggested to be involved in chemo resistance and cell } \\
\text { metastasis. Although several potential mechanisms were suggested to explain the therapeutic effect of CD47-targeting; } \\
\text { the different effects by CD47 are still not well understood. In this study, we assessed the effect of doxorubicin on }\end{array}$ \\
\hline $\begin{array}{l}\text { Key words: } \\
\text { CD47, jurkat T cells, } \\
\text { leukaemia, upregulation, } \\
\text { doxorubicin, chemotherapy, } \\
\text { apoptosis, flow cytometry. }\end{array}$ & $\begin{array}{l}\text { CD47 expression in jurkat T cells. Jurkat cells in complete medium were cultured with doxorubicin }(50-1000 \mathrm{nM}) \text { or } \\
\text { control for } 0,24,48 \text { and } 72 \text { hours. Cells were stained with anti-CD } 47 \text { FITC. Flow cytometry analysis was used for } \\
\text { measurement of fluorescence intensity. Cell viability was detected using trypan blue exclusion test. Treatment with } \\
\text { doxorubicin modulated the up-regulation of CD } 47 \text { on membrane surfaces of jurkat cells with no significant killing } \\
\text { of the cells. leukaemia cells exert their anti-apoptotic role through increased CD47 expression. CD } 47 \text { is a novel } \\
\text { functional protein in jurkat T cells with promising therapeutic potential and may provide insight for targeted therapy } \\
\text { against T-ALL disease. }\end{array}$ \\
\hline
\end{tabular}

\section{INTRODUCTION}

Acute lymphoblastic leukaemia (ALL) is a malignant disease of the bone marrow in which early lymphoid precursors proliferate and replace the normal haematopoietic cells of the marrow (Kerketta et al., 2007). ALL is the most common malignancy among children in the United States, accounting for $75 \%$ of the leukaemia cases, and is curable in $80 \%$ to $85 \%$ of the patients (Banihashem et al., 2014; Dong et al., 2013; Van Vlierberghe and Ferrando, 2012; Oudot et al., 2008; Pui et al., 2008). T cell acute lymphoblastic leukaemias (T-ALLs) are aggressive haematological tumours resulting from the malignant transformation of $\mathrm{T}$ cell progenitors (Van Vlierberghe and Ferrando, 2012). T-ALL accounts for $10 \%-15 \%$ of paediatric and $25 \%$ of adult ALL cases (Van Vlierberghe and Ferrando, 2012; Goldberg et al., 2003; Ferrando et al., 2002). Clinically, T-ALL patients show diffuse infiltration of the bone marrow by immature

\section{${ }^{*}$ Corresponding Author}

Chidozie Elochukwu Agu, Prime Health Response Initiative (PHRI)-Global Fund HIV/AIDS Project, Ilorin, Kwara State, Nigeria. E-mail: chidozieagu@gmail.com
T cell lymphoblast, high white blood cell counts, mediastinal enlargement and CNS involvement at diagnosis (Van Vlierberghe and Ferrando, 2012; Goldberg et al., 2003; Ferrando et al., 2002). The prognosis of T-ALL has gradually improved with the introduction of intensified chemotherapy, with cure rates in modern protocols reaching over $75 \%$ in children and about $50 \%$ in adults with this disease (Pui et al., 2008; Goldberg et al., 2003). However, the outcome of T-ALL patients with primary resistant or relapsed leukaemia remains poor (Oudot et al., 2008; Goldberg et al., 2003). Therefore, current research efforts are focused on the search for targets for the development of more effective and less toxic anti-leukemic drugs.

Doxorubicin (DXR) is a type of chemotherapeutic drug called an anthracycline, used to treat many types of cancer including T-ALL (Pommier et al., 2010; Park et al. 2005; Guano et al., 1999). The anticancer effects of DXR and other anthracyclines are derived from topoisomerase II blocking and the resultant apoptosis (Pommier et al., 2010; Park et al., 2005). Gamen et al. (2000) report that DXRinduced apoptosis may be mediated by the activation of caspase-9, the loss of mitochondrial membrane potential and 
the release of apoptogenic factors. However, the studies on the anticancer activity of DXR have mainly been focused on the inhibition of topoisomerase II and apoptosis induction, whereas the relationship between DXR and CD47 expression on jurkat cells has not yet been elucidated.

CD47 is a $47-52 \mathrm{kDa}$ transmembrane glycoprotein of the immunoglobulin (Ig) super-family, with an extracellular amino-terminal IgV domain, a five times transmembranespanning domain and different carboxyl-terminal cytoplasmic domains generated by alternative splicing (Uchendu et al., 2017; Oldenborg, 2004; Brown and Fraser, 2001; Reinhold et al., 1995). CD47 is heavily glycosylated (Oldenborg, 2013) with a ubiquitous expression virtually by all cells in the body including lymphocytes (Kinashi, 2005). The presence of CD47 has been shown to be crucial for immune evasion in leukaemic stem cells (Chao et al., 2012; Willingham et al., 2012; Chao et al., 2011; Chao et al., 2010; Majeti et al., 2009; Matozaki et al., 2009; van den Berg and van der Schoot, 2008). CD47 exerts its anti-phagocytic role through binding to phagocytic cells that express signal regulatory protein alpha, $\operatorname{SIRP} \alpha$ (Chao et al., 2012). Upon binding, CD47 initiates a signal transduction cascade resulting in inhibition of phagocytosis (Lee et al., 2014). CD47 activation induces apoptosis of B-cell chronic lymphocytic leukaemia cells through a caspase-independent mechanism (Mateo et al., 2002). Recently, CD47 was reported to be a marker of tumour-initiating cells in leukaemia and bladder cancer (Willingham et al., 2012).

Jurkat cells are an immortalized line of human $\mathrm{T}$ lymphocyte cells used to study acute $\mathrm{T}$ cell leukaemia, $\mathrm{T}$ cell signalling, and the expression of various chemokine receptors (Parson et al., 2005). Their primary use, however, is to study or determine the mechanism of differential susceptibility of cancer cells to drugs (Dong et al., 2013) and radiation (Cataldi et al., 2009). Although there are evidences of CD47 activities in jurkat cells, its role or interaction with DXR has not been investigated in these cells. The aim of this study was to assess the effect of DXR on CD47 expression in jurkat cells. We hypothesized that DXR may modulate the expression of CD47 on membrane surfaces of jurkat cells. Our findings may help in the development of clinical strategies using CD47 as targets to further develop novel therapy for $\mathrm{T}$ cell leukaemia in humans.

\section{MATERIALS AND METHODS}

\section{Materials}

\section{Cell line and antibodies}

Jurkat cells were purchased from ATCC, Middlesex, UK; CD47-FITC (FITC mouse anti-human CD47) and CD47control FITC (FITC mouse IgG1 k isotype control) from BD Pharmingen, UK.

\section{Chemical reagents}

Doxorubicin, hydrochloride from Calbiochem, UK; RPMI-1640 medium (Life Technologies, UK); Phosphate buffered saline, PBS (Amresco, Ohio, USA); foetal bovine serum, FBS (Hyclone, UK) and Trypan blue stain (SigmaAldrich, UK).

\section{Methods}

\section{Cell culture condition}

Jurkat cells were routinely maintained in RPMI1640 medium supplemented with $10 \%(\mathrm{v} / \mathrm{v})$ FBS and $2 \mathrm{mM}$ L-glutamine as described in American Type Culture Collection (ATCC) kit. The cells were cultured in $25 \mathrm{~cm}^{2}$ or $75 \mathrm{~cm}^{2}$ flasks at $37^{\circ} \mathrm{C}$ in a humidified $95 \%$ air and $5 \% \mathrm{CO}_{2}$ incubator. The cells were manipulated aseptically in a Class 2 BSC Laminar flow hood (Thermo Electron Corporation) and were sub-cultured every 2-3 days in order to maintain a concentration between $1 \times 10^{5}-1 \times 10^{6}$ cells $/ \mathrm{ml}$, depending on the experimental demands.

\section{Cell culture for CD47 assay}

Using a flat bottom 12 well plate, Jurkat cells $\left(1 \times 10^{6}\right.$ cells $/ \mathrm{ml}$ ) in $2 \mathrm{~mL}$ of complete RPMI medium were cultured with doxorubicin (DXR) 50nM, 100nM, 250nM, 500nM, 1000nM or control for $0,24,48$ and 72 hours at $37^{\circ} \mathrm{C}$ in a humidified $95 \%$ air and $5 \% \mathrm{CO}_{2}$ incubator.

\section{Flow cytometry analysis of CD47 expression}

Using a Gilson pipette, $200 \mu \mathrm{L}$ cell suspension from each well were transferred to $1.5 \mathrm{~mL}$ Eppendorf tubes, washed once with $1 \mathrm{~mL}$ of PBS and centrifuged at $200 \mathrm{~g}$ for 3 minutes to wash off the culture medium. Cell pellets were re-suspended in $100 \mu \mathrm{L}$ PBS and stained with $5 \mu \mathrm{L}$ CD47-FITC. Cells were immediately placed into ice bucket and shaded from light to avoid destruction of the light sensitive FITC stain; and assayed within 1 hour for CD47 expression using a Flow cytometer (BD Accuri C6). Data were obtained using CellQuest software v7.5.3 (Becton Dickinson, Oxford, UK). A minimum of 10,000 cells was analysed in each flow cytometry experiment. Each experiment was repeated three times using different cell passages to allow for means from the triplicate measurements.

\section{Cell viability using trypan blue exclusion test}

To $10 \mu \mathrm{L}$ of treatment cell suspension $\left(1 \times 10^{5}-2 \times 10^{5}\right.$ cells $/ \mathrm{mL}$ ) in Eppendorf tube was added $10 \mu \mathrm{L}$ of $0.4 \%$ (v/v) Trypan blue stain. Then gently and thoroughly mixed, using a $10 \mu \mathrm{L}$ Gilson pipette, to avoid lysing the cells and to permit homogenous staining or distribution. This was allowed to stand for 15 seconds at room temperature before the haemocytometer was charged for cell counting. Under the inverted microscope, non-viable (dead/ stained) and viable cells (live/unstained) were counted. At least 70 cells were counted to ensure accurate count. Cell concentration $/ \mathrm{ml}$ was calculated as: Average number of cells in one large square $\mathrm{x}$ dilution factor $\times 10^{4}$. Percentage viability was calculated as: (No. of viable cells counted/Total cells counted) $\times 100$.

\section{Statistical analysis}

Statistical analysis of data were completed using GraphPad prism 6 software with statistical significance $(\mathrm{p}<0.05)$, determined by using the independent two-sample students t-test or ANOVA.

\section{RESULTS}

DXR (50nM-1000nM) induced the up-regulation of CD47 after 24 hours treatment when compared to the controls 
(Figure 1). There was peak expression of CD47 at 24 hours in all the groups after which it declined at time 72 hours of incubation with DXR (Figure 1B). It was observed that CD47 up-regulation was highest with 100nM DXR and lowest with 1000nM DXR in relation to other concentrations at 24 hours and 48 hours incubation periods (Figure 1B). Quantitative flow cytometry analysis showed a substantial increase of the surface CD47 at 24 hours incubation (Figure 2).

Percentage viable cell count showed that doxorubicin (50-1000nM) did not significantly kill the CD47-expressing jurkat cells at 24-72 hours period of incubation when compared with their respective controls. Jurkat cells cultured with the various concentrations of DXR had \% cell viability of (75-95\%), (70$90 \%)$ and $(60-80 \%)$ at 24,48 and 72 hours respectively against controls (80-100\%) (Figure 3).



Fig. 1: Doxorubicin modulated the up-regulation of CD47 expression in jurkat cells at 24-72 hours incubation. (A) Histogram showing the time-course of effects from the treatment with graded concentrations of DXR. The preliminary data shows that cells treated with DXR expressed more CD47 when compared with their respective controls at 24-72 hours of incubation. (B) The preliminary data shows that there was steady increase in the expression of $\mathrm{CD} 47$ which peaked at 24 hours. It was then observed to be down-regulated after 24 hours of incubation with DXR. Note that CD47 expression was maximum with 100nM DXR followed by $250 \mathrm{nM}$ DXR. In contrast, treatment with $1000 \mathrm{nM}$ DXR was observed to produce the least $\mathrm{CD} 47$ expression. The data are presented as means $\pm \mathrm{SD}(\mathrm{A})$ or means (B) of the median fluorescent intensity of three independent experiments. Statistical analyses were performed using two-way ANOVA. See Materials and Methods for experimental details.
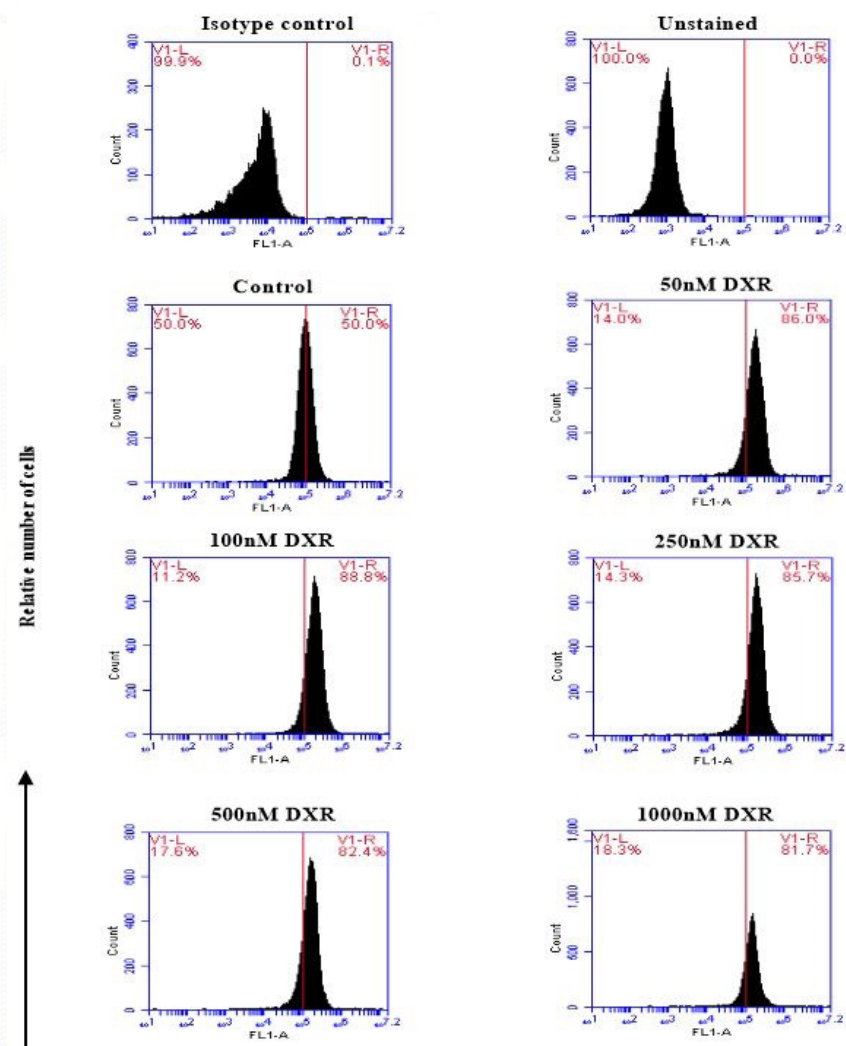

Anti-CD47 FITC

Fig. 2: Flow cytometer profile showing CD47 expression in jurkat cells after 24 hours treatment with doxorubicin. $1 \times 10^{6}$ cells $/ \mathrm{ml}$ of Jurkat cells was treated with different concentrations of DXR as described in Materials and Methods. Cells were stained with FITC mouse anti-human CD47 or FITC mouse IgG1 k isotype control. Cells treated with doxorubicin expressed more CD47 in comparison with control cells. Note the position of the first histogram, the isotype control relative to those of treatments or control (undrugged). V1-L indicates \% space left to the vertical marker, V1-R indicates \% space right to the vertical marker; FL1-A indicates the fluorescence intensity of anti-CD47 FIT-C.

\section{DISCUSSION}

Although several potential mechanisms were suggested to explain the therapeutic effect of CD47-targeting based on existing data and other studies (Chao et al., 2010; Chao et al., 2011; Majeti et al., 2009), the different effects by CD47 are still not well understood. The aim of this study was to investigate the effect of DXR on CD47 expression in jurkat cells.

Report suggests that CD47 and CD95 augment each other in jurkat T cells (Manna et al., 2005). Quesada et al. (2005) showed that DXR at doses 100 times lower than those effectively used as monotherapy significantly up-regulated endothelial CD95 in vitro and in vivo. DXR treatment triggered a sustained, p53dependent up-regulation of CD95 mRNA and consequently increased the total CD95 available for the surface presentation and ligand interaction (Quesada et al., 2005). However, study on the relationship between DXR and CD47 expression on jurkat cells has not yet been elucidated.

In this study, similar concentrations of DXR $(50 \mathrm{nM}-$ $1000 \mathrm{nM}$ ) modulated the up-regulation of CD47 in jurkat, in vitro. Up-regulation of CD47 peaked at 24 hours in all treatments after 
which it declined. However, \% viable count revealed that there was no significant death of the cells during the 72 hours treatment between treatments and respective controls. This suggests that the leukaemia cells may have resisted the drug, and hence prevented apoptosis. The post-24 hours down-regulation of CD47 observed may be due to possible blocking of the synthesis or expression of the protein, CD47 perhaps resulting from the of inhibition of topoisomerase II by DXR.

A
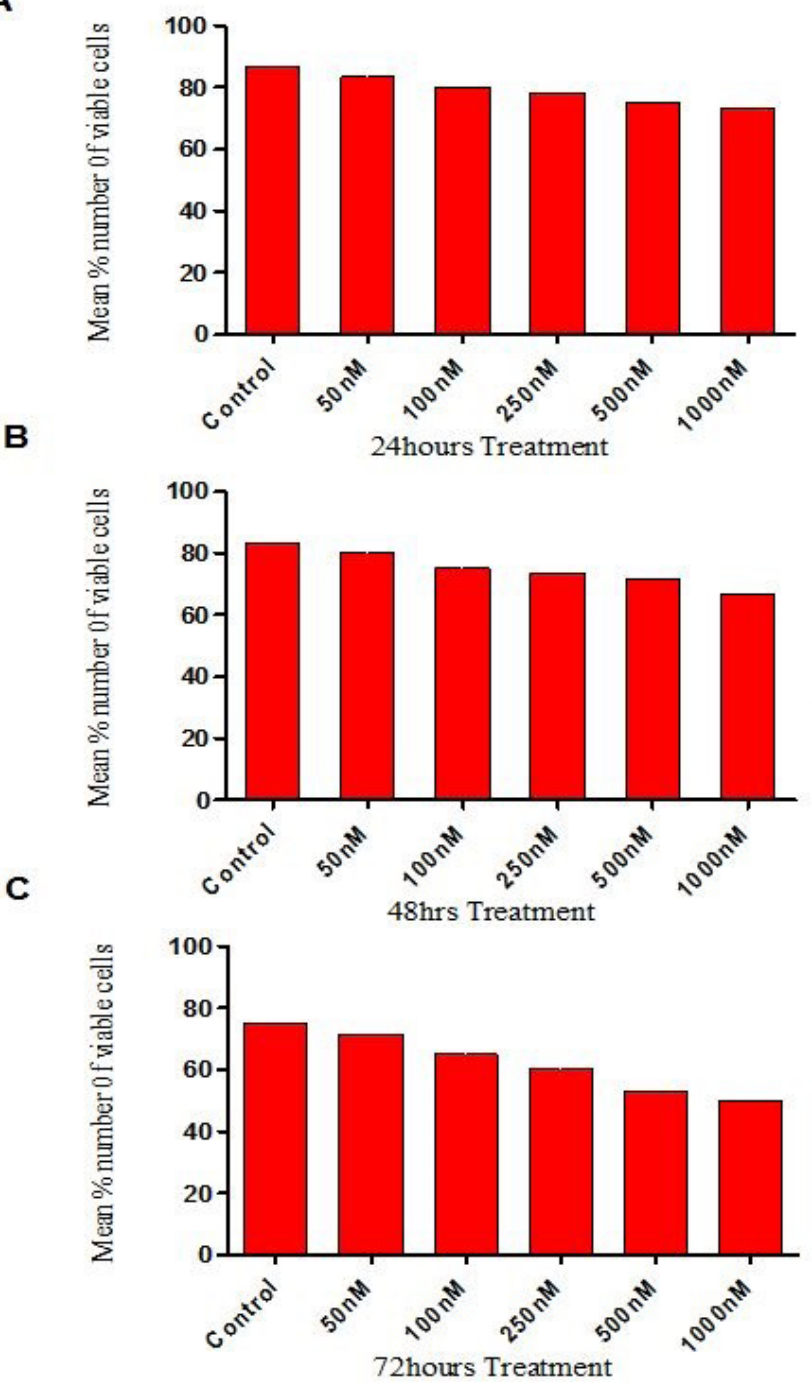

Fig. 3: Effect of doxorubicin on jurkat cells viability. Histograms show mean \% number of viable cells following cell culture with doxorubicin $(50 \mathrm{nM}, 100 \mathrm{nM}, 250 \mathrm{nM}, 500 \mathrm{nM}$, or $1000 \mathrm{nM})$ or control for $24-72$ hours. The preliminary data shows that doxorubicin did not significantly kill the CD47expressing jurkat cells at 24-72 hours period of incubation when compared with their respective controls. The data are presented as means of the $\%$ viable cell counts of individual counts from three different cell passages. Statistical analyses were performed using the Student's t-test with. See Materials and Methods for experimental details.

Several mechanisms reported to be commonly associated with cellular resistance to topoisomerase II inhibitors include: P-glycoprotein and/or multi-drug resistance-associated protein (MRP), reduction of topoisomerase II levels, changes in sub cellular localization, topoisomerase II phosphorylation and topoisomerase II mutation ( $\mathrm{Gu}$ et al., 2012; Pommier et al., 2010). In multi-drug resistance (MDR) cases, expression of $\mathrm{P}$-glycoprotein leads to abundant DXR efflux and reduction in intracellular concentration of DXR; thus, the intracellular optimal dose is never achieved (Gu et al., 2012). Findings suggest that free DXR may be taken up by cells via a passive diffusion mechanism, and may also be prone to the MDR effect (Laginha et al. 2005). Perhaps these may also explain the high \% viable cells or nonsignificance observed in this study.

Reports showed that CD47 plays a role in immune evasion in different types of leukaemia and bladder cancer and may be involved in chemo-resistance and cell metastasis (Lee et al. 2014). Increased CD47 expression was found on AML leukemic stem cells when compared with normal haematopoietic stem cell from multiple primary specimens (Majeti et al., 2009). In addition, CD47 expression was also up-regulated in tumorinitiating cells population of bladder cancer and associated with the poor prognosis of patients (Majeti et al., 2009). Since cancer tissues are believed to be more immunogenic than normal tissues, the immune evasion function of CD47 may explain the up-regulation of this protein in membrane surfaces of jurkat $\mathrm{T}$ cells as was observed in this study.

\section{LIMITATIONS AND FUTURE DIRECTION}

This study lacked the inclusion of CD47 mRNA analysis. There was limited scope or analysis to unravel if other molecules played any singular or combined role in inhibiting apoptosis in these cells. This was due to limited available fund. Several other areas have been identified that may be suitable for future work using jurkats and they include: evaluation of CD47 therapeutic value by lentiviral-based shRNA knockdown so as to assess the consequences of its suppression in jurkats; examine if CD47 plays role in chemo-resistance, by applying doxorubicin to jurkat NTC (non-target control) and jurkat shCD47 and then observe their response to apoptotic induction; investigate for properties such as tumour initiation, self-renewal, "stemness" gene expression, chemo-resistance and metastasis, which may reveal CD47 as a potential target for T-ALL.

\section{CONCLUSION}

Jurkat $\mathrm{T}$ cells upregulated the expression of the protein, CD47 and prevented cell death against the chemotherapeutic drug, doxorubicin. Therefore, leukaemia cells exert their anti-apoptotic role through increased CD47 expression. CD47 is a novel functional protein in jurkat $\mathrm{T}$ cells with promising therapeutic potential and may provide insight for targeted therapy against T-ALL disease.

\section{AUTHORS' CONTRIBUTIONS}

Conceived and designed the experiments: I.K.U, Performed the experiments: I.K.U

Analyzed the data: I.K.U., O.C.O. and C.E.A

Contributed analysis tools: B.C.E., O.C.O., C.E.A. and T.N.F

\section{ACKNOWLEDGEMENT}

The authors acknowledge Dr. Jason Mansell, Mr. Dave Corry and Dr. Jeff Davey for their advice. 


\section{COMPETING INTERESTS STATEMENT}

The authors declare no competing interests.

\section{REFERENCES}

Banihashem A, Ghasemi A, Ghaemi N, Moazzen N, Amirabadi A. Prevalence of transient hyperglycaemia and diabetes mellitus in paediatric patients with acute leukaemia. Iran J Ped Hematol Oncol 2014; 4(1):5-10.

Brown EJ, Frazier WA. Integrin-associated protein (CD47) and its ligands. Trends Cell Biol 2001; 11(3):130-135.

Cataldi A, Di Giacomo V, Rapino M, Zara S, Rana RA. Ionizing radiation induces apoptotic signal through protein kinase $\mathrm{C} \delta$ (delta) and survival signal through Akt and cyclic-nucleotide response element-binding protein (CREB) in jurkat T cells. Biol Bull. 2009; 217(2):202-212.

Chao MP, Weissman IL, Majeti R. The CD47-SIRPa Pathway in Cancer Immune Evasion and Potential Therapeutic Implications. Curr Opin Immunol 2012; 24(2):225-232.

Chao MP, Alizadeh AA, Tang C, Jan M, Weissman-Tsukamoto R, Zhao F, Park Y, Weissman IL, Majeti R. Therapeutic antibody targeting of CD47 eliminates human acute lymphoblastic leukaemia. Cancer Res 2011; 71(4):1374-1384

Chao MP, Alizadeh AA, Tang C, Myklebust JH, Varghese B, Gill S, Jan M, Cha AC, Chan CK, Tan BT, Park CY, Zhao F, Kohrt HE, Malumbres R, Briones J, Gascoyne RD, Lossos IS, Levy R, Weissman IL, Majeti R. Anti-CD47 antibody synergizes with rituximab to promote phagocytosis and eradicate non-Hodgkin lymphoma. Cell 2010; 142(5):699-713.

Dong X, Shi J, Zhou J, Chen X, Jin Y, Zhang X, Li X, Dai H, Wang J. Chemotherapy induces enhanced procoagulant activity through phosphatidylserine exposure in acute lymphoblastic leukaemia. Thromb Res 2013; 132(5):614-620.

Ferrando A.A, Neuberg DS, Staunton J, Loh ML, Huard C, Raimondi SC, Behm FG, Pui CH, Downing JR, Gilliland DG, Lander ES, Golub TR. Look AT. Gene expression signatures define novel oncogenic pathways in T cell acute lymphoblastic leukaemia. Cancer Cell 2002; 1(1):75-87.

Gamen S, Anel A, Pérez-Galán P, Lasierra P, Johnson D, Piñeiro A, Naval J. Doxorubicin treatment activates a Z-VAD-sensitive caspase, which causes deltapsim loss, caspase-9 activity, and apoptosis in Jurkat cells. Exp Cell Res 2000; 258(1):223-235.

Goldberg JM, Silverman LB, Levy DE, Dalton VK, Gelber RD, Lehmann L, Cohen HJ, Sallan SE, Asselin BL. Childhood T-cell acute lymphoblastic leukaemia: the Dana-Farber Cancer Institute acute lymphoblastic leukaemia consortium experience. J Clin Oncol 2003; 21 (19):3616-3622.

Gu YJ, Cheng J, Man CW, Wong WT, Cheng SH. Gold-doxorubicin nanoconjugates for overcoming multidrug resistance. Nanomedicine 2012; 8(2):204-211

Guano F, Pourquier P, Tinelli S, Binaschi M, Bigioni M, Animati F, Manzini S, Zunino F, Kohlhagen G, Pommier Y, Capranico G. Topoisomerase poisoning activity of novel disaccharide anthracyclines. Mol Pharmacol 1999; 56(1):77-84.

Uchendu IK, Orji OC, Agu CE, Eluke BC, Chukwu IJ, Nnedu EB, Nwosu TF, Preliminary Study on the Role of Protein Kinase C in Cd47Mediated Phosphatidylserine Exposure Pathway By Bric 126 In Jurkat T Cells. Der Pharmacia Lettre, 2017; 9 (8):18-28.

Kerketta L, Vundinti BR, Ghosh K. Translocation t (2; 14) (p13; $\mathrm{q} 32$ ) in a case of $\mathrm{Ph}+$ acute lymphoblastic leukaemia. Indian J Hum Genet 2007; 13(3):125-126.

Kinashi T. Intracellular signalling controlling integrin activation in lymphocytes. Nat Rev Immunol 2005; 5(7):546-559.

Lee TK, Cheung VC, Lu P, Ting Lau EY, Ma S, Tang KH, Tong M, Lo J, Ling I. Blockade of CD47-mediated cathepsin s/protease-activated receptor2 signaling provides a therapeutic target for hepatocellular carcinoma.
Hepatology 2014; 60(1):179-191.

Majeti R, Chao MP, Alizadeh AA, Pang WW, Jaiswal S, Gibbs Jr. $\mathrm{KD}$, van Rooijen N, Weissman IL. CD47 is an adverse prognostic factor and therapeutic antibody target on human acute myeloid leukaemia stem cells. Cell 2009; 138:286-299.

Manna PP, Dimitry J, Oldenborg PA, Frazier WA. CD47 Augments Fas/CD95-mediated Apoptosis. J. Biol Chem 2005; 280:29637-29644.

Mateo V, Brown EJ, Biron G, Rubio M, Fischer A, Deist FL, Sarfati M. Mechanisms of CD47-induced caspase-independent cell death in normal and leukemic cells: link between phosphatidylserine exposure and cytoskeleton organization. Blood 2002; 100:2882-2890.

Oldenborg PA. CD47: A cell surface glycoprotein which regulates multiple functions of haematopoietic cells in health and disease. ISRN Hematol. 2013; 2013:614-619

Oldenborg PA. Role of CD47 in erythroid cells and in autoimmunity. Leuk Lymphoma 2004; 45:1319-1327.

Oudot C, Auclerc MF, Levy V, Porcher R, Piguet C, Perel Y, Gandemer V, Debre M, Vermylen C, Pautard B, Berger C, Schmitt C, Leblanc T, Cayuela JM, Socie G, Michel G, Leverger G, Baruchel A. Prognostic factors for leukemic induction failure in children with acute lymphoblastic leukaemia and outcome after salvage therapy: the FRALLE 93 study. $J$ Clin Oncol 2008; 26(9):1496-1503.

Park HJ, Chung HJ, Min HY, Park EJ, Hong JY, Kim WB, Kim SH, Lee SK. Inhibitory effect of DA-125, a new anthracycline analog anti-tumour agent, on the invasion of human fibrosarcoma cells by down-regulating the matrix metalloproteinases. Biochem Pharmacol 2005; 71(1-2):21-31.

Parson W, Kirchebner R, Mühlmann R, Renner K, Kofler A, Schmidt S, Reinhard K. Cancer cell line identification by short tandem repeat profiling: power and limitations. FASEB J. 2005; 19(3):434-436.

Pommier Y, Leo E, Zhang H, Marchand C. DNA topoisomerases and their poisoning by anti-cancer and anti-bacterial drugs. Chem Biol 2010; 17(5):421-433.

Pui CH, Robison LL, Look AT. Acute lymphoblastic leukaemia. Lancet 2008; 371 (9617):1030-1043.

Quesada AJ, Nelius T, Yap R, Zaichuk TA, Alfranca A, Filleur S, Volpert OV, Redondo JM. In vivo upregulation of CD95 and CD95L causes synergistic inhibition of angiogenesis by TSP1 peptide and metronomic doxorubicin treatment. Cell Death Differ 2005; 12(6):649-658.

Reinhold MI, Lindberg FP, Plas D, Reynolds S, Peters MG., Brown E. J. In vivo expression of alternatively spliced forms of integrinassociated protein (CD47). J Cell Sci 1995; 108(11):3419-3425.

Van Vlierberghe P., Ferrando A. The molecular basis of T cell acute lymphoblastic leukemia. J Clin Invest. 2012; 122(10):3398-3406.

Willingham SB, Volkmer JP, Gentles AJ, Sahoo D, Dalerba P, Mitra SS, Wang J, Contreras-Trujillo H, Martin R, Cohen JD, Lovelace P, Scheeren FA, Chao MP, Weiskopf K, Tang C, Volkmer A.K, Naik T.J, Storm TA, Mosley AR, Edris B, Schmid SM, Sun CK, Chua MS, Murillo O, Rajendran P, Cha AC, Chin RK, Kim D, Adorno M, Raveh T, Tseng D, Jaiswal S, Enger P, Steinberg GK, Li G, So SK, Majeti R, Harsh GR, van de Rijn M, Teng NN, Sunwoo JB, Alizadeh AA, Clarke MF, Weissman IL. The CD47-signal regulatory protein alpha (SIRPa) interaction is a therapeutic target for human solid tumors. Proc Natl Acad Sci U S A 2012; 109(17):66626667

How to cite this article:

Uchendu IK, Orji OC, Agu CE, Chekwube BE, Nwosu TF. CD47 is Up-Regulated on Leukaemia Cells to Avoid Apoptosis in Vitro: Application in AST assay diagnostic kit. J App Pharm Sci, 2018; 8(03): 099-103. 